\title{
Sistem Pendukung Keputusan Kelompok Pemilihan Tempat PKL Mahasiswa dengan Menggunakan Metode AHP dan Borda
}

\author{
Dirja Nur Ilham*1, Sri Mulyana ${ }^{2}$ \\ ${ }^{1}$ Program studi S2 Ilmu Komputer FMIPA UGM, Yogyakarta \\ ${ }^{2}$ Departemen Ilmu Komputer dan Elektronika, FMIPA UGM, Yogyakarta \\ e-mail:*1dirja_nur@yahoo.com, 2smulyana@ugm.ac.id
}

\begin{abstract}
Abstrak
Penempatan Praktek Kerja Lapangan (PKL) yang tepat untuk mahasiswa merupakan suatu hal yang sangat penting, karena bisa memaksimalkan kemampuan dan bakat dari setiap mahasiswa sehingga menghasilkan mahasiswa lulusan yang siap bersaing di dunia kerja. Dalam pemilihan tempat PKL mahasiswa di Politeknik Aceh Selatan, masalah yang sering terjadi adalah ketidaksesuaian kompetensi dari segi kebutuhan perusahaan tempat PKL, maupun kebutuhan mahasiswa akan tempat PKL. Untuk mengatasi masalah tersebut diperlukan suatu sistem komputer berupa sistem pendukung keputusan kelompok (GDSS) yang dapat membantu Politeknik Aceh Selatan untuk pemilihan tempat PKL yang tepat bagi mahasiswa. Sistem pendukung keputusan kelompok yang dikembangkan dalam penelitian ini menggunakan metode AHP (Analytical Hierarchy Process) dan Borda untuk penentuan keputusan kelompok. Metode AHP digunakan untuk penentuan bobot kriteria dan subkriteria dari setiap alternatif perusahaan tempat PKL hingga perangkingan alternatif perusahan untuk masing-masing mahasiswa dari setiap pengambil keputusan. Metode Borda digunakan untuk penggabungan hasil perangkingan yang didapat oleh setiap pengambil keputusan sehingga mendapatkan perangkingan akhir dan menentukan rekomendasi tempat PKL mahasiswa. Berdasarkan hasil akhir dari Sistem pendukung keputusan kelompok berupa perankingan dari nilai kriteria mahasiswa terhadap alternatif perusahaan tempat PKL. Dan alternatif perusahaan yang mendapatkan hasil tertinggi dijadikan sebagai rekomendasi pengambilan keputusan penempatan PKL mahasiswa prodi teknik komputer politeknik aceh selatan.
\end{abstract}

Kata kunci-SPKK, AHP, Borda, Praktek Kerja Lapangan

\begin{abstract}
The right Placement Job Training (PKL) selection for the students is a very important thing, because it can maximize the abilities and talents of each student so that can produce graduates who are ready to compete in the world of work. The most common problem of PKL selection is the lack of competence in terms of the needs of the company, as well as the needs of students will be on PKL place selection. To overcome these problems required a computer system in the form of group decision support systems (GDSS) who can help South Aceh Polytechnic for the selection of the right vendors for students. In this study, Group decision support system developed by using AHP (Analytical Hierarchy Process) and Borda for group decision-making. AHP method is used to determine the weights of criteria and sub-criteria of each company where PKL alternative to alternative perangkingan company for each student from each of the decision makers. Borda method used for incorporation gradement results obtained by each decision maker so getting rank final and decisive recommendations $P K L$ student places. Based on the outcome of a group decision support system in the form of a rank of criteria values of students to alternative company where PKL placement selection. And alternative companies that get the highest yield serve as recommendations PKL student placement decisions for computer engineering department Polytechnics South Aceh.
\end{abstract}

Keywords-GDSS, AHP, Borda, field practice 


\section{PENDAHULUAN}

Drogram Praktek Kerja Lapangan (PKL) adalah salah satu syarat seorang mahasiswa untuk bisa mengambil tugas akhir yang berlaku untuk mahasiswa Diploma 3 (D3), Diploma 4 (D4), dan juga Sarjana (S1) pada umumnya, baik pada Politeknik, Sekolah Tinggi, Akademi, Institut maupun Universitas yang ada di Indonesia. Pemilihan tempat yang tepat bagi mahasiswa yang akan melakukan PKL merupakan salah satu langkah yang baik agar kriteria yang dibutuhkan oleh institusi dan perusahaan terpenuhi dengan baik sesuai dengan kemampuan dari mahasiswa yang masuk ke institusi/perusahaan.

Kordinator PKL, kaprodi, dan dosen pembimbing PKL seringkali mengalami kesulitan untuk menentukan tempat PKL. Seringkali dalam pemilihan tempat PKL tidak sesuai dengan kemampuan yang dimiliki oleh mahasiswa. Sehingga mahasiswa tidak bias menggunakan kemampuan yang dimilikinya secara optimal. Tidak sesuainya penempatan PKL mahasiswa ini disebabkan oleh beberapa factor seperti:

a.Kemampuan mahasiswa tidak sesuai dengan kebutuhan yang diinginkan instansi/perusahaan tempat PKL.

b. Proses penilaian pemilihan tempat PKL mahasiswa berdasarkan subyektifitas. Kemungkinan bahwa tempat PKL yang dipilih tidak memenuhi standar yang diinginkan dan tidak sesuai dengan kompetensi mahasiswa.

Pengambilan keputusan dalam penilaian pemilihan tempat PKL mahasiswa yang dilakukan kordinator PKL, kaprodi, dan dosen pembimbing PKL di lingkungan Politeknik Aceh Selatan belum menghasilkan informasi yang akurat dan cepat, ditambah lagi karena masih dilakukan secara manual. Maka dalam penelitian ini akan dibuat sebuah sistem yang diharapkan bisa membantu dalam mengambil keputusan. Sistem Pendukung Keputusan Kelompok (SPKK) dapat membantu pengambilan keputusan bagi pihak pengambi keputusan dalam memilih tempat PKL yang tepat untuk mahasiswa. SPKK/ GDSS merupakan sebuah sistem berbasis komputer yang mendukung sekelompok orang yang tergabung dalam suatu tugas/ tujuan bersama yang menyediakan interface yang dapat digunakan bersama [1].

AHP umumnya digunakan dengan tujuan untuk menyusun prioritas dari berbagai alternatif/pilihan yang ada dan pilihan-pilihan tersebut bersifat kompleks atau multi kriteria. Secara umum, dengan menggunakan AHP, prioritas yang dihasilkan akan bersifat konsisten dengan teori, logis, transparan, dan partisipatif [2].

Berdasarkan latar belakang yang sudah diterangkan, maka topik penelitian yang diajukan adalah " Sistem Pendukung Keputusan Kelompok Pemilihan Tempat PKL Mahasiswa dengan Menggunakan Metode AHP dan Borda". penelitian ini diharapkan dapat memecahkan masalah pemilihan tempat PKL mahasiswa dalam pengambilan keputusan secara kelompok.

\subsection{Sistem Pendukung Keputusan}

Sistem pendukung keputusan digunakan sebagai alat bantu bagi para pengambil keputusan untuk memperluas kapabilitas para pengambil keputusan, namun tidak untuk menggantikan penilaian para pengambil keputusan. SPK ditujukan untuk keputusan yang memerlukan penilaian atau untuk keputusan-keputusan yang sama sekali tidak dapat didukung oleh algoritma. SPK meluas dengan cepat, dari sekedar alat pendukung personal menjadi komoditas yang dipakai bersama [3]. Tahapan proses pengambilan keputusan terdiri dari beberapa langkah, yaitu : (a) Tahap Penelusuran (Intelligence), (b) Tahap Perancangan (Design), (c) Tahap Pemilihan (Choice), dan (d) Tahap Implementasi (Implementation).

\subsection{Sistem Pendukung Keputusan Kelompok}

Sistem pendukung keputusan kelompok (Group Decision Support System) adalah "sebuah sistem berbasis komputer yang mendukung sekelompok orang yang tergabung dalam suatu tugas (atau tujuan) bersama yang menyediakan interface yang dapat digunakan bersama".

IJCCS Vol. 11, No. 1, January 2017 : $55-66$ 
Group Decision Support System (GDSS) adalah sistem berdasarkan komputer yang interaktif yang memudahkan pemecahan atas masalah semi terstruktur dan tidak terstruktur oleh beberapa pembuat keputusan yang bekerja sama sebagai suatu kelompok [1].

\section{METODE PENELITIAN}

\subsection{Analytical Hierarchy Process (AHP)}

Metode AHP merupakan salah satu metode yang dapat digunakan dalam sistem pengambilan keputusan dengan memperhatikan faktor-faktor persepsi, preferensi, pengalaman dan intuisi. Pada dasarnya, metode AHP memecah-mecah suatu situasi yang kompleks dan tak terstruktur ke dalam bagian-bagian komponennya. Kemudian menata bagian atau variabel ini dalam suatu susunan hirarki dan memberi nilai numerik pada pertimbangan subjektif tentang relatif pentingnya setiap variabel. Setelah itu mensintesis berbagai pertimbangan ini untuk menetapkan variabel mana yang memiliki prioritas paling tinggi dan bertindak untuk mempengaruhi hasil pada situasi tersebut [4].

Dalam menyelesaikan masalah dengan menggunakan metode AHP, ada beberapa prinsip dasar yang perlu dipahami, yaitu :

1. Dekomposisi (penyusunan hirarki), yaitu proses menganalisis permasalahan yang nyata ke dalam struktur hirarki atas unsur-unsur pendukungnya. Implementasi penyusunan striktur hiraki dapat dilihat pada Gambar 1.

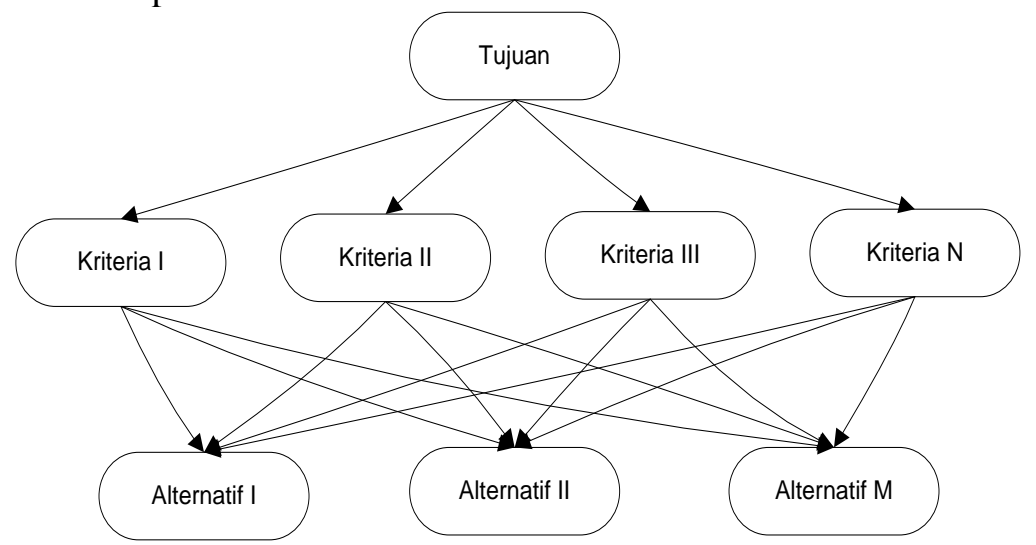

Gambar 1 Struktur Hirarki AHP [5]

2. Penilaian komparatif (Comparative Judgement), dilakukan dengan penilaian tentang kepentingan relatif dua elemen. Hasil dari penilaian ini disajikan dalam bentuk matriks perbandingan berpasangan (pairwise comparison matrix) yang memuat tingkat preferensi antar setiap kriteria. Skala preferensi yang digunakan yaitu skala tingkat Kepentingan [6]. Nilai skala perbandingan yang digunakan sebagai inputan data dapat dilihat pada Tabel 1.

Tabel 1 Skala Tingkat Kepentingan

\begin{tabular}{|c|c|}
\hline Nilai & Interpretasi \\
\hline 1 & Jika $\mathrm{O}_{\mathrm{i}}$ dan $\mathrm{O}_{\mathrm{j}}$ sama penting \\
\hline 3 & Jika $\mathrm{O}_{\mathrm{i}}$ sedikit lebih penting daripada $\mathrm{O}_{\mathrm{j}}$ \\
\hline 5 & Jika $\mathrm{O}_{\mathrm{i}} \mathrm{kuat}$ tingkat kepentingannya daripada $\mathrm{O}_{\mathrm{j}}$ \\
\hline 7 & Jika $\mathrm{O}_{\mathrm{i}}$ sangat kuat tingkat kepentingannya daripada $\mathrm{O}_{\mathrm{j}}$ \\
\hline 9 & Jika $\mathrm{O}_{\mathrm{i}}$ mutlak lebih penting daripada $\mathrm{O}_{\mathrm{j}}$ \\
\hline $2,4,6,8$ & Nilai-nilai antara dua nilai pertimbangan yang berdekatan \\
\hline Kebalikan & $\begin{array}{l}\text { Jika aktivitas I mendapat satu angka dibandingkan dengan } \\
\text { aktivitas j, maka j memiliki nilai kebalikannya dibandingkan } \\
\text { dengan i }\end{array}$ \\
\hline
\end{tabular}


3. Setelah matriks perbandingan berpasangan terbentuk, maka langkah berikutnya adalah menentukan bobot prioritas elemen (kriteria). Penentuan bobot prioritas kriteria yang digunakan yaitu metode Additive Normalization (AN). Dalam [7], Saaty menyatakan bahwa, untuk menentukan bobot prioritas dengan metode Additive Normalization (AN) dapat dilakukan dengan cara :

a. Menjumlahkan nilai dari setiap kolom dalam matriks perbandingan berpasangan menggunakan persamaan (1).

$$
\sum_{i=1}^{n} a_{i j} \text {, dengan } \mathrm{i}, \mathrm{j}=1,2, \ldots, \mathrm{n} .
$$

b. Membagi setiap nilai dari kolom dengan total kolom yang bersangkutan untuk memperoleh normalisasi matriks menggunakan persamaan (2).

$$
a_{i j}^{\sigma}=\frac{a_{i j}}{\sum_{i=1}^{n} a_{i j}} \text {, dengan } \mathrm{i}, \mathrm{j}=1,2, \ldots, \mathrm{n} .
$$

dimana adalah nilai elemen matriks ternormalisasi pada baris ke-i kolom ke-j.

c. Menjumlahkan semua nilai setiap baris dari matriks yang telah dinormalisasi dan membaginya dengan jumlah elemen. Hasil pembagian tersebut menunjukkan nilai bobot prioritas untuk setiap elemen (kriteria) menggunakan persamaan (3)

$$
w_{i}^{T}=\frac{\sum_{j=1}^{n} a_{i j}}{n}, \text { dengan } \mathrm{i}, \mathrm{j}=1,2, \ldots, \mathrm{n}
$$

4. Mengukur konsistensi. Hal-hal yang dilakukan dalam langkah ini adalah :

a. Menghitung nilai $\lambda_{\max }$. Menyatakan bahwa nilai $\lambda_{\max }$ dapat ditentukan dengan persamaan (4) [8].

$$
\lambda_{\max }=\frac{1}{n} \sum_{i=1}^{n} \frac{\left(A w^{T}\right)_{i}}{w_{i}^{T}}
$$

dimana $\mathrm{n}$ adalah banyak elemen matriks, $\mathrm{A}$ adalah matriks perbandingan berpasangan, dan $w^{T}$ adalah matriks bobot prioritas (eigenvector).

b. Menghitung Consistency Index (CI) menggunakan persamaan (5).

$$
\mathrm{CI}=\frac{\lambda_{\operatorname{maks}}-n}{n-1}
$$

c. Menghitung Consistency Ratio (CR) menggunakan persamaan (6).

$$
\mathrm{CR}=\frac{C I}{I R}
$$

5. Mencari peringkat/rangking alternatif dari matriks pairwise masing-masing alternatif dengan menentukan eigenvector setiap alternatif [4]. Cara yang digunakan sama dengan membuat peringkat prioritas diatas.

a. Menentukan matriks pairwise comparisons masing-masing alternatif

b. Menentukan nilai eigenvector masing-masing alternatif

c. Menentukan peringkat alternatif

Peringkat/rangking alternatif dapat ditentukan dengan mengalikan nilai eigenvector alternatif dengan eigenvector kriteria.

Apabila nilai $\mathrm{CR} \leq 0.1$ maka dapat disimpulkan matriks perbandingan berpasangan yang dibuat sudah konsisten. Namun jika nilai CR $>0.1$ maka penilaian prioritas harus diperbaiki [9]. Daftar Index Random Consistency (IR) dapat dilihat pada Tabel 2.

Tabel 2 Nilai Index Random Consistency (IR)

\begin{tabular}{|c|c|c|c|c|c|c|c|c|c|}
\hline$n$ & 2 & 3 & 4 & 5 & 6 & 7 & 8 & 9 & 10 \\
\hline Nilai IR & 0 & 0.58 & 0.90 & 1.12 & 1.24 & 1.32 & 1.41 & 1.45 & 1.49 \\
\hline
\end{tabular}




\subsubsection{Borda}

Metode Borda merupakan metode voting yang dapat menyelesaikan pengambilan keputusan kelompok, dimana dalam penerapannya masing-masing decision maker memberikan peringkat berdasarkan alternatif pilihan yang ada, proses pemilihan dalam metode Borda, masing-masing voter diberikan alternatif pilihan. Di misalkan ada $\mathrm{n}$ kandidat pilihan, kandidat atau alternatif pertama diberikan $\mathrm{n}$ poin oleh voter atau decisian maker. Kandidat kedua diberikan poin n-1 dan seterusnnya. Penentuan pemenang atau alternatif terbaik berdasarkan poin yang tertinggi. Alternatif dengan nilai tertinggi merupakan bahan pertimbangan yang akan dipilih [10]. Implementasi metode Borda dapat dilihat pada Tabel 3.

Tabel 3 Implementasi metode Borda

\begin{tabular}{|c|c|c|c|c|c|c|}
\hline \multirow[t]{2}{*}{ Voter / Decision Maker } & \multicolumn{4}{|c|}{ Kandidat / Alternatif Pilihan } & Ranking & Poin \\
\hline & A & B & $\mathrm{C}$ & $\mathrm{D}$ & & \\
\hline 1 & 2 & 1 & 4 & 3 & 1 & 3 \\
\hline 2 & 3 & 1 & 4 & 2 & 2 & 2 \\
\hline 3 & 1 & 2 & 3 & 4 & 3 & 1 \\
\hline Perhitungan Metode Borda & 6 & 8 & 1 & 3 & 4 & 0 \\
\hline
\end{tabular}

Masing-masing Decision Maker melakukan analisa alternatif pilihan yang ada. Alternatif pilihan dengan peringkat pertama diberikan poin tertinggi, misalnya peringkat pertama diberikan poin 3, peringkat kedua diberikan poin 2, peringkat 3 diberikan poin 1 , peringkat keempat diberikan poin 0 . Nilai poin dari hasil pengambilan keputusan masingmasing decision maker dijumlahkan secara keseluruhan. Hasil perhitungan metode Borda dengan melibatkan nilai poin alternatif A yaitu $(2+1+3)=6$, alternatif $\mathrm{B}(3+3+2)=8$, alternatif $\mathrm{C}(0+0+1)=1$ dan alternatif $\mathrm{D}(1+2+0)=3$. Berdasarkan hasil perhitungan metode Borda diatas, maka dapat disimpulkan bahwa nilai poin tertinggi adalah alternatif pilihan B.

\subsubsection{Praktek Kerja Lapangan}

Praktek Kerja Lapangan (PKL) merupakan kegiatan praktek kerja bagi mahasiswa yang dilakukan diluar kampus. Mahasiswa di Politeknik Aceh Selatan khususnya pada Program Studi Teknik Komputer diberikan pembekalan keterampilan praktik dalam bidangnya secara umum sebelum para mahasiswa ditempatkan di perusahaan/industri, setelah diberikan pembekalan barulah mahasiswa ditempatkan sesuai dengan kompetensi yang paling dikuasainya oleh pihak program studi.

\section{2 Diagram Konteks}

Diagram alir data atau DFD (data flow diagram) berguna untuk mengetahui kebutuhan sistem dan member gambaran yang jelas dan lengkap kepada pembuat program dalam membuat sistem perangkat lunak. Pada diagram konteks ditunjukkan dua tipe pengguna yaitu Admin dan Decision Maker. Untuk dapat menggunakan sistem, terlebih dahulu user melakukan login. Admin bertugas memasukkan data decision maker, data perusahaan, data kriteria, data subkriteria, data mahasiswa, dan data nilai mahasiswa. Sedangkan decision maker melakukan perbandingan berpasangan antar kriteria dan antar subkriteria untuk setiap alternatif perusahaan tempat PKL mahasiswa. Diagram konteks terlihat pada Gambar 2. 


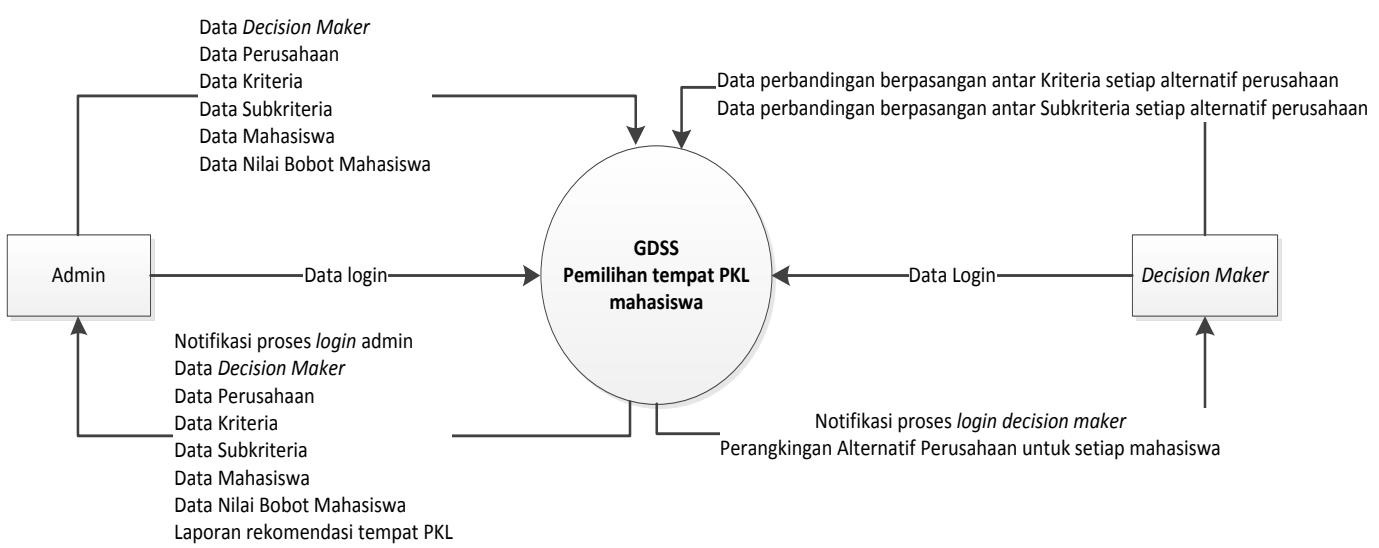

Gambar 2 Diagram Konteks

\section{3 Gambaran Sistem}

Sistem yang dirancang dan dibangun dalam penelitian ini adalah sistem yang dapat merekomendasikan tempat PKL bagi mahasiswa di di prodi teknik komputer Politeknik Aceh Selatan. Adapun beberapa data yang dibutuhkan adalah data perusahaan yang akan dijadikan alternatif tempat PKL mahasiswa, data kriteria, data subkriteria, data decision maker, data mahasiswa. Dalam penelitian ini digunakan 4 kriteria yang memiliki masing-masing subkriteria seperti yang terlihat pada Tabel 4 .

Tabel 4 Kriteria Pemilihan tempat PKL

\begin{tabular}{|c|c|c|}
\hline No & Kriteria & Subkriteria \\
\hline 1 & Akademik & IPK \\
\hline 2 & Bidang Keahlian & Jaringan \\
\hline & & Perangkat Keras \\
\hline & & Penrograman \\
\hline 3 & Kepribadian & Komunikasi \\
\hline & & Etika \\
\hline & & Dasar Komputer \\
\hline & & \\
& & \\
\hline 4 & Kemampuan Mahasiswa & Algoritma Pemrograman \\
\hline & & Jaringan Komputer \\
\hline & & Basis Data \\
\hline & & Sistem Operasi \\
\hline & & Pemrograman Terstruktur \\
\hline & & Arsitektur Komputer \\
\hline & & Struktur Data \\
\hline & &
\end{tabular}


Arsitektur sistem yang digunakan dalam Group Decision Support system pemilihan tempat PKL mahasiswa, merupakan hubungan yang dapat dilihat antara komponen-komponen yang berhubungan pada sistem. Arsitektur sistem dapat dilihat pada Gambar 3.

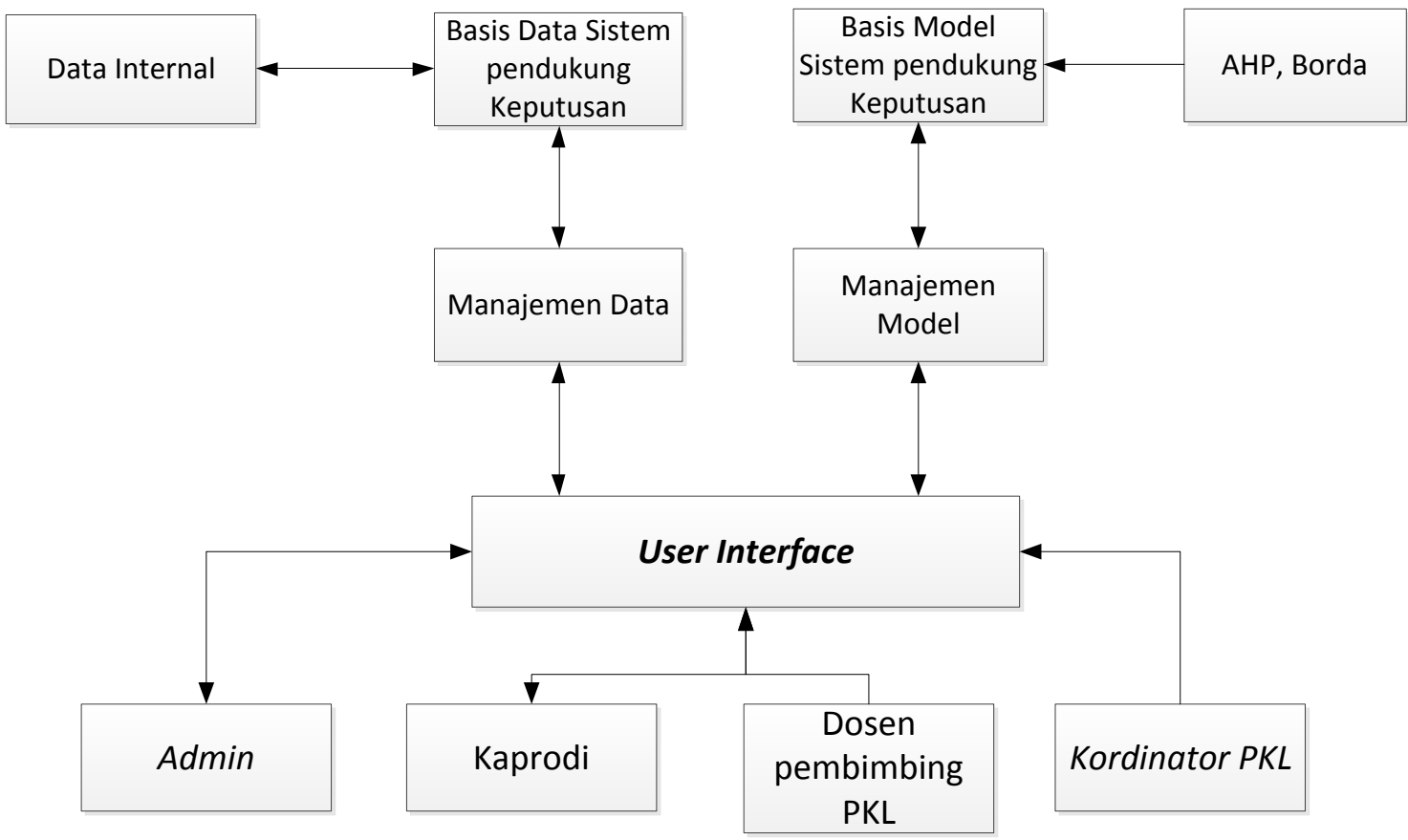

Gambar 3 Gambaran Sistem

\section{HASIL DAN PEMBAHASAN}

\subsection{Pengujian proses perhitungan AHP}

Pengujian proses perhitungan AHP merupakan proses pengujian bobot kriteria, bobot subkriteria, bobot kriteria global, pembobotan setiap perusahaan untuk masing-masing mahasiswa yang dilakuakan oleh setiap decision maker.

Pengujian perhitungan bobot kriteria global diperoleh dari perkalian bobot kriteria dengan bobot subkriteria perusahaan alternatif tempat PKL yang didapat dari setiap decision maker yaitu kaprodi, dosen pembimbing PKL, dan kordinator PKL. Hasil pengujian perhitungan bobot kriteria global dari para decision maker terdiri dari sebelas perusahaan yang menjadi alternatif perusahaan. Pada Gambar 4. Ditunjukkan bobot hasil kriteria, bobot hasil subkriteria, dan bobot hasil kriteria global yang didapat dari proses perhitungan menggunakan metode AHP. 


\begin{tabular}{l|l|l|l|l}
\hline Kriteria & Bobot & Subriteria & Bobot & Bobot Kriteria Global \\
\hline Akademik & 0.558 & IPK & 1 & 0.558 \\
\hline Bidang Keahlian & 0.263 & Jaringan & 0.557 & 0.147 \\
\hline Bidang Keahlian & 0.263 & Perangkat Keras & 0.32 & 0.084 \\
\hline Bidang Keahlian & 0.263 & Pemrograman & 0.123 & 0.032 \\
\hline Kemampuan Mahasiswa & 0.057 & Dasar Komputer & 0.107 & 0.006 \\
\hline Kemampuan Mahasiswa & 0.057 & Algoritma Pemrograman & 0.038 & 0.002 \\
\hline Kemampuan Mahasiswa & 0.057 & Jaringan Komputer & 0.314 & 0.018 \\
\hline Kemampuan Mahasiswa & 0.057 & Basis Data & 0.021 & 0.001 \\
\hline Kemampuan Mahasiswa & 0.057 & Sistem Operasi & 0.066 & 0.004 \\
\hline Kemampuan Mahasiswa & 0.057 & Pemrograman Terstruktur & 0.042 & 0.002 \\
\hline Kemampuan Mahasiswa & 0.057 & Keamanan Jaringan & 0.218 & 0.012 \\
\hline Kemampuan Mahasiswa & 0.057 & Arsitektur Komputer & 0.153 & 0.009 \\
\hline Kemampuan Mahasiswa & 0.057 & Struktur Data & 0.041 & 0.002 \\
\hline Kepribadian & 0.122 & Penampilan & 0.198 & 0.024 \\
\hline Kepribadian & 0.122 & Komunikasi & 0.312 & 0.038 \\
\hline Kepribadian & 0.122 & Etika & 0.49 & 0.06 \\
\hline
\end{tabular}

Gambar 4 Hasil perhitungan pembobotan

\subsection{Hasil pembobotan nilai mahasiswa terhadap alternatif perusahaan}

Hasil pengujian pembobotan setiap mahasiswa terhadap setiap alternatif perusahaan diperoleh dari perkalian nilai kriteria dari mahasiswa dengan bobot kriteria global setiap alternatif perusahaan yang didapat dari setiap decision maker. Hasil perhitungan pembobotan nilai mkahasiswa terhadap alternatif perusahaan ditunjukkan pada Gambar 5.

\begin{tabular}{|c|c|c|c|c|c|c|c|c|c|c|c|}
\hline Kriteria & P01 & $\mathrm{PO2}$ & $\mathrm{PO3}$ & P04 & P05 & P06 & P07 & P08 & P09 & P10 & P11 \\
\hline AK1 & 1.4617 & 1.4617 & 1.4617 & 1.4617 & 1.4617 & 1.4617 & 1.4617 & 1.4617 & 1.4617 & 1.4617 & 1.4617 \\
\hline BK1 & 0.4402 & 0.5004 & 0.0839 & 0.1816 & 0.4258 & 0.0932 & 0.1317 & 0.1055 & 0.1055 & 0.1317 & 0.4402 \\
\hline BK2 & 0.253 & 0.2058 & 0.2058 & 0.5119 & 0.2348 & 0.1591 & 0.5267 & 0.167 & 0.5176 & 0.1317 & 0.253 \\
\hline BK3 & 0.0969 & 0.0839 & 0.5004 & 0.0965 & 0.1294 & 0.5377 & 0.1317 & 0.5176 & 0.167 & 0.5267 & 0.0969 \\
\hline KM1 & 0.0183 & 0.0173 & 0.0359 & 0.0363 & 0.022 & 0.0371 & 0.0369 & 0.0371 & 0.0369 & 0.0484 & 0.022 \\
\hline KM2 & 0.0043 & 0.0048 & 0.0126 & 0.0052 & 0.0054 & 0.0174 & 0.0119 & 0.0174 & 0.0119 & 0.0217 & 0.0054 \\
\hline KM3 & 0.0357 & 0.0351 & 0.007 & 0.0106 & 0.0331 & 0.0027 & 0.008 & 0.0027 & 0.008 & 0.0078 & 0.0331 \\
\hline KM4 & 0.0035 & 0.0048 & 0.046 & 0.0036 & 0.0046 & 0.0523 & 0.0033 & 0.0523 & 0.0033 & 0.0203 & 0.0046 \\
\hline KM5 & 0.0112 & 0.0125 & 0.0094 & 0.025 & 0.014 & 0.0182 & 0.0258 & 0.0182 & 0.0258 & 0.0117 & 0.014 \\
\hline KM6 & 0.0048 & 0.0052 & 0.0126 & 0.0048 & 0.0054 & 0.0055 & 0.0036 & 0.0055 & 0.0036 & 0.0046 & 0.0054 \\
\hline KM7 & 0.0371 & 0.0373 & 0.0058 & 0.0158 & 0.022 & 0.004 & 0.012 & 0.004 & 0.012 & 0.0117 & 0.022 \\
\hline KM8 & 0.0174 & 0.0158 & 0.0062 & 0.0345 & 0.0226 & 0.0083 & 0.0347 & 0.0083 & 0.0347 & 0.0135 & 0.0226 \\
\hline KM9 & 0.0047 & 0.0048 & 0.0107 & 0.0048 & 0.0054 & 0.0055 & 0.0036 & 0.0055 & 0.0036 & 0.0046 & 0.0054 \\
\hline KP1 & 0.0723 & 0.0723 & 0.0723 & 0.0723 & 0.0723 & 0.0723 & 0.0723 & 0.0723 & 0.0723 & 0.0723 & 0.0723 \\
\hline KP2 & 0.114 & 0.114 & 0.114 & 0.114 & 0.114 & 0.114 & 0.114 & 0.114 & 0.114 & 0.114 & 0.114 \\
\hline KP3 & 0.2391 & 0.2391 & 0.2391 & 0.2391 & 0.2391 & 0.2391 & 0.2391 & 0.2391 & 0.2391 & 0.2391 & 0.2391 \\
\hline Total & 2.8143 & 2.8149 & 2.8233 & 2.8178 & 2.8118 & 2.8281 & 2.8169 & 2.8281 & 2.8169 & 2.8216 & 2.8118 \\
\hline
\end{tabular}

Gambar 5 Hasil pembobotan nilai mahasiswa terhadap alternatif 
Setelah didapatkan hasil pembobotan nilai mahasiswa terhadap alternatif perusahaan maka akan didapatkan nilai bobot setiap mahasiswa dari para decision maker untuk semua alternatif perusahaan yang ada. Pembobotan total dari setiap decision maker ditunjukkann pada Gambar 6.

\begin{tabular}{|c|c|c|c|c|}
\hline Mahasiswa & Perusahaan & DOSEN PEMBIMBING PKL & KAPRODI & KORDINATOR PKL \\
\hline AUFIYA RULIANDA & PT. TELKOM, TbK Kandatel Banda Aceh & 3.0823 & 2.8143 & 2.868 \\
\hline AUFIYA RULIANDA & PT. PLN Wilayah Aceh & 3.0825 & 2.8149 & 2.868 \\
\hline AUFIYA RULIANDA & PT. Lafarge Cement Indonesia/SAI & 3.1045 & 2.8233 & 2.8919 \\
\hline AUFIYA RULIANDA & PT. ARUN NGL ACEH & 3.0887 & 2.8178 & 2.8746 \\
\hline AUFIYA RULIANDA & PT. Pupuk Iskandar Muda & 3.0812 & 2.8118 & 2.8666 \\
\hline AUFIYA RULIANDA & PT. DYNEA MUGI INDONESIA LANGSA & 3.1043 & 2.8281 & 2.8919 \\
\hline AUFIYA RULIANDA & PT. Sang Hyang Seri Persero IV & 3.0882 & 2.8169 & 2.8744 \\
\hline AUFIYA RULIANDA & PT. Perkebunan Nusantara II & 3.1043 & 2.8281 & 2.8921 \\
\hline AUFIYA RULIANDA & PT. Logikreasi Utama Medan & 3.0885 & 2.8169 & 2.8752 \\
\hline AUFIYA RULIANDA & PT. Telkom, Tbk Divisi Multimedia Medan & 3.0974 & 2.8216 & 2.8819 \\
\hline AUFIYA RULIANDA & PT. TELKOMSEL MEDAN & 3.0812 & 2.8118 & 2.8667 \\
\hline
\end{tabular}

Gambar 6 Hasil total bobot dari setiap decision maker

\subsection{Penentuan score terhadap alternatif perusahaan}

Sebelum dilakukan proses penentuan score terlebih dahulu dilakukan perangkingan alternatif perusahaan untuk setiap mahasiswa untuk mendapatkan nilai bobot score yang akan dihitung dengan menggunakan metode Borda. Hasil perangkingan alternative ditunjukkan pada Gambar 7, dan Hasil penentuan score akhir ditunjukkan pada Gambar 8.

\begin{tabular}{|c|c|c|c|c|}
\hline Mahasiswa & Perusahaan & DOSEN PEMBIMBING PKL & KAPRODI & KORDINATOR PKL \\
\hline AUFIYA RULIANDA & PT. TELKOM, Tbk Kandatel Banda Aceh & 9 & 7 & 7 \\
\hline AUFIYA RULIANDA & PT. PLN Wilayah Aceh & 8 & 6 & 7 \\
\hline AUFIYA RULIANDA & PT. Lafarge Cement Indonesia/SAI & 1 & 2 & 2 \\
\hline AUFIYA RULIANDA & PT. ARUN NGL ACEH & 5 & 4 & 5 \\
\hline AUFIYA RULIANDA & PT. Pupuk Iskandar Muda & 11 & 8 & 9 \\
\hline AUFIYA RULIANDA & PT. DYNEA MUGI INDONESIA LANGSA & 3 & 1 & 2 \\
\hline AUFIYA RULIANDA & PT. Sang Hyang Seri Persero IV & 7 & 5 & 6 \\
\hline AUFIYA RULIANDA & PT. Perkebunan Nusantara II & 2 & 1 & 1 \\
\hline AUFIYA RULIANDA & PT. Logikreasi Utama Medan & 6 & 5 & 4 \\
\hline AUFIYA RULIANDA & PT. Telkom, Tbk Divisi Multimedia Medan & 4 & 3 & 3 \\
\hline AUFIYA RULIANDA & PT. TELKOMSEL MEDAN & 10 & 8 & 8 \\
\hline
\end{tabular}

Gambar 7 Perangkingan alternatif perusahaan setiap mahasiswa 


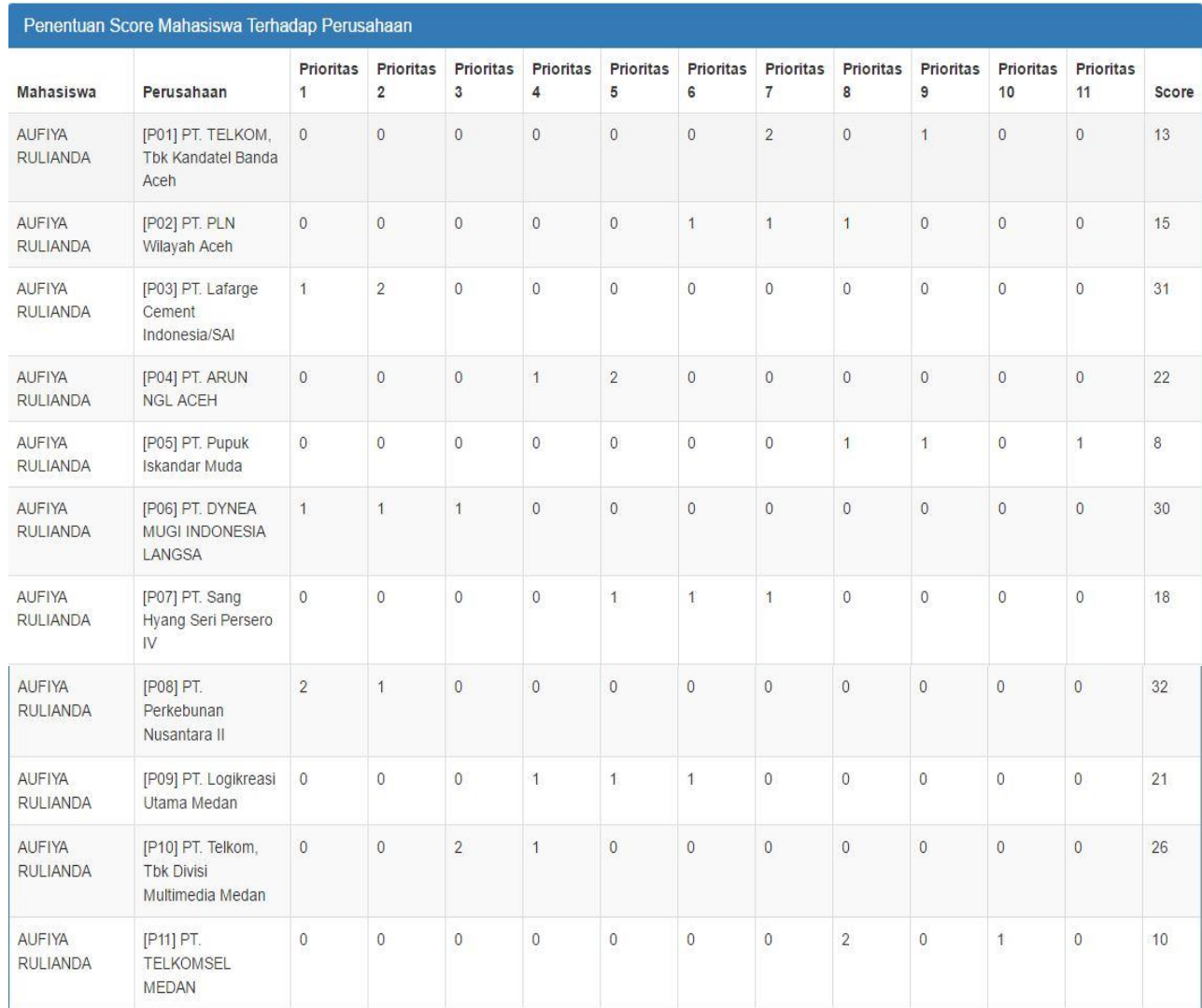

Gambar 8 Perhitungan score prioritas alternatif perusahaan

\subsection{Hasil rekomendasi akhir tempat PKL setiap mahasiswa}

Hasil rekomendasi disini didapat dari nilai score tertinggi dari setiap mahasiswa setelah melalui proses perangkingan untuk setiap alternatif perusahaan dengan jumlah kuota penerimaan yang dibutuhkan. Sehingga hasil akhir rekomendasi tempat PKL mahasiswa tidak selalu merupakan prioritas pertama, karena bisa jadi prioritas ke dua dan seterusnya. Hasil rekomendasi pemilihan tempat PKL mahasiswa ditunjukkan pada Gambar 9.

\begin{tabular}{|l|l|l|}
\hline Rekomentasi Tempat PKL untuk Setiap Mahasiswa & & \\
\hline Perusahaan & Mahasiswa & score \\
\hline PT. Perkebunan Nusantara II & ANTON FITRI & 32 \\
\hline PT. Perkebunan Nusantara II & AUFIYA RULIANDA & 32 \\
\hline PT. Perkebunan Nusantara II & SULFITRA RAMADHA & 32 \\
\hline PT. DYNEA MUGI INDONESIA LANGSA & RIZQAN THAYYIBI & 32 \\
\hline PT. DYNEA MUGI INDONESIA LANGSA & SHINTA SARTINA & 31 \\
\hline PT. DYNEA MUGI INDONESIA LANGSA & IGA PURNAMA SARI & 31 \\
\hline PT. Lafarge Cement Indonesia/SAI & NURLIANI & 31 \\
\hline PT. Lafarge Cement Indonesia/SAI & SINTA AMELIA & 29 \\
\hline PT. Lafarge Cement Indonesia/SAI & ANDRIANI & 29 \\
\hline PT. Sang Hyang Seri Persero IV & IKHWAN ZUHRI & 30 \\
\hline PT. Sang Hyang Seri Persero IV & FAJRI & 30 \\
\hline PT. Logikreasi Utama Medan & VIVIANTI & 31 \\
\hline PT. Logikreasi Utama Medan & ANDITA ISNANDAR & 18 \\
\hline PT. TELKOMSEL MEDAN & KHAIRUL ILHAMI & 30 \\
\hline
\end{tabular}

Gambar 9 Hasil rekomendasi perusahaan tempat PKL 


\section{KESIMPULAN}

Kesimpulan yang diperoleh dalam penelitian pemilihan tempat PKL mahasiswa di prodi teknik komputer Politeknik Aceh Selatan dengan menggunkan metode AHP dan Borda adalah:

1. Sistem ini dapat membantu dalam pengambilan keputusan mengenai pemilihan tempat PKL mahasiswa pada program studi teknik komputer Politeknik Aceh Selatan.

2. Sistem yang dibangun bersifat dinamis karena parameter yang digunakan dalam pengambilan keputusan dapat ditambah, diubah dan dihapus, demikian juga dengan nilai perbandingan berpasangan kriteria, subkriteria dan data alternatif perusahaan yang menggunakan metode AHP dapat diubah, sehingga mempengaruhi hasil pengambilan keputusan.

3. Penerapan metode AHP dan Borda dalam pemilihan tempat PKL mahasiswa sudah sesuai dengan tujuan yang diharapkan.

\section{SARAN}

Dari hasil penelitian diatas, terdapat beberapa hal yang perlu ditambahkan dan dikembangkan dari sistem pendukung keputusan kelompok pemilihan tempat PKL mahasiswa adalah:

1. Penelitian terkait pemilihan tempat PKL mahasiswa ini dapat dikembangkan dengan memanfaatkan metode-metode keputusan lain, misalnya menggunakan metode ANP.

2. Proses pemilihan tempat PKL mahasiswa dapat menerapkan kombinasi metode yang lain sehingga dapat dijadikan perbandingan bobot atau ranking yang di hasilkan.

\section{DAFTAR PUSTAKA}

[1] Turban, E., Sharda, R., dan Delen, D., 2011, Decisian Support System and Business Intelligence System, ninth Edition, Prentice Hall, New Jersey, USA.

[2] Bourgeois, R. 2005. Analytical Hierarchy Process: an Overview, UNCAPSA-UNESCAP. Bogor.

[3] Turban, E., Aronson, J.E. \& Liang, T.-P.,, 2005. Decision support systems and intelligent system (Sistem Pendukung Keputusan dan Sistem Cerdas), Edisi 7 Jilid 1, Diterjemahkan Oleh : Dwi Prabantini, ANDI OFFSET Yogyakarta.

[4] Saaty, Thomas L., 1993, Pengambilan Keputusan Bagi Para Pemimpin, Proses Hirarki Analitik Untuk Pengmbilan Keputusan Dalam Situasi Yang Kompleks, Pustaka Binama Pressindo, Jakarta.

[5] Meng, M., 2013. The Research and Application of the Risk Evaluation and Management of Information Security Based on AHP Method and PDCA Method. International Conference on Information Management, Inovation Management and Industrial Engineering, pp.379383.

[6] Reenoij, S., 2005, Multi Attribute Decision Making Under Certainty, The Analytic Hierarcy Process. 
[7] Srdjevic, B., 2005, Combining different prioritization methods in the analytic hierarchy process synthesis, Elsevier.

[8] Kusumadewi, S., Hartati, S., Harjoko, A., dan Wardoyo, R., 2006, Fuzzy Multi Attribute Decision Making. Graha Ilmu Yogyakarta.

[9] Saaty, T. and Vargas,L., 2001, Models, Methods, Concepts and Application of The Analytic Hierarchy Process, Sepringer Science Business New York.

[10] Wang, C.W.C. \& Leung, H.L.H., 2004. A secure and fully private borda voting protocol with universal verifiability. Proceedings of the 28th Annual International Computer Software and Applications Conference, 2004. COMPSAC 2004. 